\title{
Peningkatan Keterampilan Menulis Tegak Bersambung Melalui Metode Guided Writing di kelas II SDN 02 Macanan
}

\section{Wahyu Drajad Sitaresmi}

Universitas Sebelas Maret

wdsitaresmi@student.uns.ac.id

\section{Article History}

received 30/4/2021

\begin{abstract}
The objective of this research is to raise cursive handwriting skills at the second grade through the use of Guided Writing method in the googlemeet learning. Every cycle consists of planning, action, observation, dan reflection. The subjects are 10 students and teacher of the second grade. Techniques of data collection are observation, interview, test, and documentation. Validity data test techniques used triangulation. Data analysis technique consists of collecting, reducting, displaying, and drawing conclusion. The outcome of this research, the class' average on pre-action is 54,50 with classical complement which is $30 \%$. First cycle increases to 68,13 with classical complement is 50\%. Second cycle increases to 76,13 with classical complement $70 \%$. Third cycle increases to 81,38 with classical complement is $90 \%$. The conclusion is the use of Guided Writing method can raise curvise handwriting skills at students on the second grade of SDN 02 Macanan at the academic year 2020/2021.
\end{abstract}

Keywords: Guided Writing method, cursive handwriting skill, second grade, elementary school

\begin{abstract}
Abstrak
Tujuan penelitian ini adalah untuk meningkatkan keterampilan menulis tegak bersambung pada peserta didik kelas 2 melalui penggunaan metode Guided Writing dalam pembelajaran googlemeet. Setiap siklus pada PTK ini meliputi perencanaan, pelaksanaan tindakan, observasi, dan refleksi. Subjek penelitian ada 10 peserta didik dan guru kelas 2. Teknik pengumpulan data yang digunakan yaitu observasi, wawancara, tes, dan dokumentasi. Tes uji validitas datanya menggunakan triangulasi. Teknik analisis datanya meliputi pengumpulan, reduksi, penyajian data, dan penarikan kesimpulan. Hasil penelitian ini nilai rata-rata kelas pada pratindakan 54,50 dengan ketuntasan klasikan $30 \%$. Siklus I meningkat nilai rata-rata kelas menjadi 68,13 dengan ketuntasan klasikal $50 \%$. Siklus II meningkat nilai rata-rata kelasnya menjadi 76,13 dengan ketuntasan klasikal $70 \%$. Siklus III meningkat kembali nilai rata-rata kelasnya menjadi 81,39 dengan ketuntasan klasikal 90\%. Simpulan penelitian ini yaitu penggunaan metode Guided Writing dapat meningkatkan keterampilan menulis tegak bersambung pada peserta didik kelas II SDN 02 Macanan tahun ajaran 2020/2021.

Kata kunci: Metode Guided Writing, Keterampilan Menulis Tegak Bersambung, Kelas dua, Sekolah Dasar
\end{abstract}




\section{PENDAHULUAN}

Bahasa Indonesia merupakan bahasa nasional yang digunakan di seluruh wilayah Indonesia sebagai bahasa pemersatu bangsa. Menurut Slamet (2014), pengajaran bahasa Indonesia adalah pengajaran keterampilan berbahasa bukan pengajaran tentang kebahasaan. Keterampilan bahasa Indonesia yang diajarkan pada jenjang sekolah dasar meliputi 4 keterampilan dasar yaitu keterampilan menulis, keterampilan membaca, keterampilan berbicara, dan keterampilan menyimak.

Keterampilan menulis di sekolah dasar dibagi menjadi dua yaitu menulis permulaan dan menulis lanjutan. Menulis permulaan diajarkan di kelas I dan II, sedangkan di kelas III-VI diajarkan menulis lanjutan. Pada pembelajaran kelas II, salah satu keterampilan menulis permulaan yang diajarkan yaitu menulis tegak bersambung. Menurut Sharp \& Brown (2015), keterampilan menulis tegak bersambung merupakan kegaiatan menyalin huruf dengan memperhatikan kaidah penulisan. Materi pembelajaran menulis tegak bersambung di kelas II yaitu mencermati penggunaan huruf kapital di awal kalimat, awal nama bulan, awal nama hari, awal nama orang serta penggunaan tanda titik pada kalimat berita dan tanda tanya pada kalimat tanya (Permendikbud, 2016).

Penguasaan keterampilan menulis tegak bersambung pada peserta didik SDN 02 Macanan kelas II masih kurang. Berdasarkan observasi, peserta didik kesulitan menulis tegak bersambung huruf $b ; d ; f ; g ; l ; r ; t$, masih keliru dalam menulis panjang pendeknya huruf tegak bersambung, dan masih kesulitan menulis huruf kapital di awal kalimat menggunakan huruf tegak bersambung. Guru kelas II mengatakan bahwa pengajaran menulis tegak bersambung terkendala perbedaan buku tulis halus yang dimiliki masing-masing peserta didik dan kurangnya bimbingan secara pribadi pada peserta didik secara langsung karena hanya bisa memberikan tugas melalui whatsapp. Peserta didik menyatakan bahwa menulis tegak bersambung sulit karena tulisannya berangkai. Hasil tes pratindakan menunjukkan hanya 3 peserta didik (30\%) yang mendapatkan nilai setara atau lebih dari KKM $(\geq 75)$, sedangkan 7 peserta didik lainnya $(70 \%)$ nilainya masih di bawah KKM. Hal tersebut menjadi bukti bahwa keterampilan menulis tegak bersambung pada peserta didik kelas II SDN 02 Macanan tergolong rendah.

Upaya peningkatan keterampilan menulis tegak bersambung di kelas II dapat dilakukan salah satunya melalui penggunaan metode Guided Writing. Menurut Daryanto (2017), metode Guided Writing merupakan cara yang paling efektif dan efisien untuk mengajarkan konsep dan keterampilan-keterampilan kepada peserta didik. Melalui metode Guided Writing guru dapat terbantu ketika memberikan bimbingan dan arahan kepada peserta didik dalam setiap tahapan menulis yang dilaluinya (Kusniarti, 2015). Dengan demikian melalui metode Guided Writing ini diharapkan peserta didik kelas II dapat menguasai keterampilan menulis tegak bersambung secara benar dan bisa meningkat hasil belajarnya.

Temuan penelitian keterampilan menulis tegak bersambung oleh Dianimdri (2019) di SDN Bumi I No. 67 Surakarta kelas II dapat meningkat melalui penggunaan metode Struktural Analitik Sintetik (SAS). Selanjutnya temuan penelitian penggunaan metode Guided Writing oleh Nurlatifah (2020) pada peserta didik SDI Al-Azhar 7 Kota Sukabumi kelas 5B dapat meningkatkan keterampilan menulis deksripsi.

Berdasarkan latar belakang masalah dan temuan penelitian yang telah diuraikan, rumusan masalah pada penelitian ini antara lain: 1) Bagaimana penggunaan metode Guided Writing untuk meningkatkan keterampilan menulis tegak bersambung di kelas II SDN 02 Macanan tahun ajaran 2020/2021?; 2) Apakah penggunaan metode Guided Writing dapat meningkatkan keterampilan menulis tegak bersambung di kelas II SDN 02 Macanan tahun ajaran 2020/2021?; dan 3) Bagaimana kendala dan solusi dalam penggunaan metode Guided Writing untuk meningkatkan keterampilan menulis tegak bersambung di kelas II SDN 02 Macanan tahun ajaran 2020/2021? 
Mengacu pada rumusan masalah di atas, maka tujuan penelitian ini meliputi: 1) Mendeskripsikan peningkatan keterampilan menulis tegak bersambung melalui penggunaan metode Guided Writing di kelas II SDN 02 Macanan tahun ajaran 2020/2021; 2) Meningkatkan keterampilan menulis tegak bersambung melalui penggunaan metode Guided Writing di kelas II SDN 02 Macanan tahun ajaran 2020/2021; dan 3) Mendeskripsikan kendala dan solusi dalam penggunaan metode Guided Writing untuk meningkatkan keterampilan menulis tegak bersambung di kelas II SDN 02 Macanan tahun ajaran 2020/2021.

\section{METODE}

Penelitian ini merupakan Penelitian Tindakan Kelas dengan pendekatan kualitatif. Subjek penelitian ini yaitu peserta didik SDN 02 Macanan kelas II tahun ajaran 2020/2021. Data yang dikumpulkan pada penelitian ini meliputi: hasil wawancara guru dan peserta didik; hasil observasi kinerja guru dan aktivitas peserta didik; hasil tes pratindakan, siklus I, siklus II, dan siklus III; serta dokumen pembelajaran menulis tegak bersambung.

Sumber data dalam penelitian ini yaitu sumber data primer dan sumber data sekunder. Peserta didik dan guru kelas II SDN 02 Macanan tahun ajaran 2020/2021 merupakan sumber data primer. Sedangkan sumber data sekunder yaitu berupa dokumen yang digunakan dalam penelitian meliputi silabus dan RPP serta dokumen berupa foto maupun video rekaman proses pembelajaran.

Penelitian ini teknik pengumpulan datanya menggunakan observasi, wawancara, dokumentasi, dan tes. Teknik uji validitas datanya meliputi triangulasi sumber dan triangulasi teknik. Analisis data yang dilakukan menggunakan teknik deskriptif komparatif maupun teknik analisis data interaktif Miles and Huberman. Adapun prosedur penelitiannya diselenggarakan dalam tiga siklus yang masing-masing meliputi tahap perencanaan, pelaksanaan tindakan, observasi, dan refleksi.

Pada penelitian ini apabila $80 \%$ peserta didik meinimal mendapatkan nilai yang termasuk kategori terampil dan tuntas $\mathrm{KKM} \geq 75$, maka penggunaan metode Guided Writing dapat meningkatkan keterampilan menulis tegak bersambung.

\section{HASIL DAN PEMBAHASAN}

Penelitian ini dilaksanakan melalui lima tahapan pada metode Guided Writing, meliputi: 1) Tahap orientasi; 2) Tahap Presentasi/ Demonstrasi; 3) Tahap Latihan Terstruktur; 4) Tahap Latihan Terbimbing; dan 5) Tahap Latihan Mandiri.

Berdasarkan hasil tes pratindakan didapatkan data bahwa hanya ada tiga peserta didik yang tuntas $\mathrm{KKM} \geq 75$. Tabel 1 menyajikan hasil data pada tes pratindakan.

Tabel 1. Distribusi Frekuensi Nilai Keterampilan Menulis Tegak Bersambung Pratindakan

\begin{tabular}{cccccc}
\hline No. & Interval Nilai & Nilai Tengah $\left(\mathbf{x}_{\mathbf{i}}\right)$ & Frekuensi (f) & $\mathbf{f .} \mathbf{x}_{\mathbf{i}}$ & Persentase (\%) \\
\hline 1. & $30-42$ & 36 & 4 & 144 & 40 \\
2. & $43-55$ & 49 & 2 & 98 & 20 \\
3. & $56-68$ & 62 & 1 & 62 & 10 \\
4. & $69-81$ & 75 & 1 & 150 & 20 \\
5. & $82-94$ & 88 & 88 & 542 & 100 \\
\hline \multicolumn{5}{c}{ Jumlah } \\
\hline \multicolumn{5}{c}{ Rata-rata $=54,50$} \\
\hline \multicolumn{5}{c}{ Nilai tertinggi $=85$} \\
\hline
\end{tabular}


Tabel 2 memperlihatkan nilai rata-rata kelas ketika pratindakan yaitu 54,50 dengan nilai terendahnya yakni 30 dan nilai tertingginya 85 . Hasil tes pratindakan menunjukkan hanya ada tiga peserta didik yang memenuhi KKM (30\%), sedangkan 7 peserta didik lainnya belum memenuhi KKM (70\%).

Setelah digunakan metode Guided Writing pada pembelajaran di kelas II SDN 02 Macanan, keterampilan peserta didik dalam menulis tegak bersambung meningkat pada siklus I. Adapun sajian data siklus I yakni:

Tabel 2. Distribusi Frekuensi Nilai Keterampilan Menulis Tegak Bersambung Siklus I

\begin{tabular}{|c|c|c|c|c|c|}
\hline No. & Interval Nilai & Nilai Tengah $\left(x_{i}\right)$ & Frekuensi (f) & f. $x_{i}$ & Persentase (\%) \\
\hline 1. & $31-44$ & 37,5 & 2 & 75 & 20 \\
\hline 2. & $45-58$ & 51,5 & 1 & 51,5 & 10 \\
\hline 3. & $59-72$ & 65,5 & 2 & 131 & 20 \\
\hline 4. & $73-86$ & 79,5 & 3 & 238,5 & 30 \\
\hline 5. & $87-100$ & 93,5 & 2 & 187 & 20 \\
\hline & Jum & & 10 & 683 & 100 \\
\hline \multicolumn{6}{|c|}{ Rata-rata $=68,13$} \\
\hline \multicolumn{6}{|c|}{ Ketuntasan klasikal $=50 \%$} \\
\hline \multicolumn{6}{|c|}{ Nilai tertinggi $=95$} \\
\hline \multicolumn{6}{|c|}{ Nilai terendah $=35$} \\
\hline
\end{tabular}

Berdasarkan tabel 2 di atas pada siklus I sebanyak 5 peserta didik sudah memenuhi KKM (50\%), sedangkan 5 peserta didik lainnya masih belum memenuhi KKM (50\%). Pada siklus I ini rata-rata nilainya bertambah menjadi 68,13 dengan perolehan nilai paling rendah yaitu 35 dan nilai paling tinggi 95 . Hasil tersebut belum memenuhi target indikator kinerja penelitian, sehingga penelitian diteruskan ke siklus II.

Setelah dilaksanakan siklus II, peningkatan keterampilan peserta didik dalam menulis tegak bersambung menjadi lebih baik daripada peningkatan siklus I. Berikut disajikan tabel 3 yang memuat data hasil siklus II:

Tabel 3. Distribusi Frekuensi Nilai Keterampilan Menulis Tegak Bersambung Siklus II

\begin{tabular}{|c|c|c|c|c|c|}
\hline No. & Interval Nilai & Nilai Tengah $\left(\mathbf{x}_{\mathrm{i}}\right)$ & Frekuensi (f) & f. $x_{i}$ & Persentase (\%) \\
\hline 1. & $36-48$ & 42 & 1 & 42 & 10 \\
\hline 2. & $49-61$ & 55 & 2 & 110 & 20 \\
\hline 3. & $62-74$ & 68 & 0 & 0 & 0 \\
\hline 4. & $75-87$ & 81 & 4 & 324 & 40 \\
\hline 5. & $88-100$ & 94 & 3 & 282 & 30 \\
\hline & Jum & & 10 & 758 & 100 \\
\hline \multicolumn{6}{|c|}{ Rata-rata $=76,13$} \\
\hline \multicolumn{6}{|c|}{ Ketuntasan klasikal = 70\% } \\
\hline \multicolumn{6}{|c|}{ Nilai tertinggi $=96,25$} \\
\hline \multicolumn{6}{|c|}{ Nilai terendah $=43,75$} \\
\hline
\end{tabular}

Berdasarkan tabel 3 di atas pada siklus II sebanyak 7 peserta didik sudah memenuhi KKM (70\%), sedangkan 3 peserta didik lainnya masih belum memenuhi KKM (30\%). Pada siklus II ini rata-rata nilainya meningkat menjadi 76,13 dengan perolehan nilai terendahnya 43,75 dan nilai tertingginya 96,25. Hasil tersebut masih belum memenuhi target indikator kinerja penelitian, akibatnya penelitian diteruskan ke siklus III.

Setelah dilaksanakan siklus III, peningkatan keterampilan menulis tegak bersambung pada peserta didik kelas II SDN 02 Macanan menjadi jauh lebih baik dari siklus II. Berikut sajian data hasil siklus III: 
Tabel 4. Distribusi Frekuensi Nilai Keterampilan Menulis Tegak Bersambung Siklus III

\begin{tabular}{|c|c|c|c|c|c|}
\hline No. & Interval Nilai & Nilai Tengah (xi) & Frekuensi (f) & f.xi & Persentase (\%) \\
\hline 1. & $56-64$ & 60 & 1 & 60 & 10 \\
\hline 2. & $65-73$ & 69 & 0 & 0 & 0 \\
\hline 3. & $74-82$ & 78 & 5 & 390 & 50 \\
\hline 4. & $83-91$ & 87 & 2 & 174 & 20 \\
\hline 5. & $92-100$ & 96 & 2 & 192 & 20 \\
\hline & Jun & & 10 & 816 & 100 \\
\hline \multicolumn{6}{|c|}{ Rata-rata $=81,38$} \\
\hline \multicolumn{6}{|c|}{ Ketuntasan klasikal $=90 \%$} \\
\hline \multicolumn{6}{|c|}{ Nilai tertinggi $=97,5$} \\
\hline & & Nilai tere & $h=58,75$ & & \\
\hline
\end{tabular}

Tabel 4 menerangkan bahwa pada siklus III sebanyak 9 peserta didik sudah memenuhi KKM $(90 \%)$, sedangkan 1 peserta didik (10\%) belum memenuhi KKM. Rata-rata nilainya meningkat menjadi 81,38 dengan perolehan nilai paling rendah yakni 58,75 dan nilai paling tinggi 97,5 . Hasil tersebut sudah melampaui target indikator kinerja penelitian yaitu $80 \%$ atau 8 peserta didik tuntas KKM, sehingga penelitian dihentikan sampai siklus III. Selanjutnya data pratindakan, siklus I, siklus II, dan siklus III dibuat perbandingan dan disajikan seperti berikut:

Tabel 5. Perbandingan Hasil Analisis Data pada Pratindakan, Siklus I, Siklus II, dan Siklus III

\begin{tabular}{cccccc}
\hline No. & Keterangan & Pratindakan & Siklus I & Siklus II & Siklus III \\
\hline 1. & Nilai rata-rata & 54,50 & 68,13 & 76,13 & 81,38 \\
2. & Nilai tertinggi & 85 & 95 & 96,25 & 97,5 \\
3. & Nilai terendah & 30 & 35 & 43,75 & 58,75 \\
4. & Persentase Ketuntasan & $30 \%$ & $50 \%$ & $70 \%$ & $90 \%$ \\
\hline
\end{tabular}

Tabel 5 menerangkan bahwa kondisi awal nilai rata-rata 54,50 naik pada siklus I menjadi 68,13 , naik lagi pada siklus I menjadi 76,13 , dan naik lagi pada siklus III menjadi 81,38 . Perolehan nilai paling tinggi pada kondisi awal 85 meningkat menjadi 95 pada siklus I, 96,25 pada siklus II, dan 97,5 pada siklus III. Perolehan nilai paling rendah 30 pada kondisi awal membaik pada siklus I menjadi 35, membaik kembali pada siklus II menjadi 43,75, dan membaik lagi menjadi 58,75 pada siklus III. Persentase ketuntasan klasikal pada kondisi awal 30\% (3 peserta didik) meningkat menjadi 50\% (5 peserta didik) pada siklus I, meningkat menjadi 70\% (7 peserta didik) pada siklus II, dan kembali meningkat pada siklus III menjadi $90 \%$ (9 peserta didik).

Hasil penelitian pada siklus II telah berhasil mencapai target indikator kinerja penelitian, artinya upaya peningkatan keterampilan menulis tegak bersambung sudah berhasil dilakukan. Meskipun demikian, masih terdapat 1 peserta didik yang belum memenuhi KKM. Berdasarkan informasi dari guru kelas II dan pengamatan selama pembelajaran googlemeet, peserta didik tersebut sulit fokus pada pembelajaran dan tergolong rendah kemampuannya dalam menulis. Upaya penanganan terhadap peserta didik yang belum memenuhi KKM tersebut yaitu dengan memberikan bimbingan langsung ketika mengumpulkan tugas ke sekolah dan diberitahukan kepada guru kelas agar mendapatkan bimbingan yang lebih intensif lagi. 
Berdasarkan uraian di atas dapat disimpulkan bahwa keterampilan menulis tegak bersambung peserta didik kelas II SDN 02 Macanan tahun ajaran 2020/2021 dapat meningkat melalui penggunaan metode Guided Writing. Setelah diselenggarakan siklus I, siklus II, dan siklus III, keterampilan peserta didik dalam menulis tegak bersambung meningkat. Pernyataan tersebut didukung oleh hasil penelitian Hana Nurlatifah bahwa metode Guided Writing dapat meningkatkan keterampilan menulis deskripsi. Metode Guided Writing dapat membantu peserta didik menulis apapun yang didahului dengan pemberian contoh (Virgiawan, 2020). Dengan demikian metode ini dapat membimbing peserta didik untuk memiliki keterampilan menulis secara bertahap dengan diawali pemberian contoh atau presentasi/ demonstrasi guru. Kemudian peserta didik menirukan melalui latihan terstruktur dan bisa dibimbing langsung oleh guru pada tahap latihan terbimbing. Hal tersebut sejalan dengan pendapat Gibson (2009) yang mengemukakan bahwa kerangka panduan Guided Writing meliputi keterlibatan semua peserta didik dalam menggali pengetahuan, pemberian presentasi, waktu menulis secara individu dengan bimbingan guru, dan kegiatan berbagi karya atau mengkomunikasikan karya masing-masing kepada guru dan peserta didik lain.

\section{SIMPULAN}

Mengacu pada hasil penelitian yang telah diuraikan di atas, dapat disimpulkan bahwa keterampilan menulis tegak bersambung bisa meningkat melalui penggunaan metode Guided Writing. Penggunaan metode Guided Writing untuk meningkatkan keterampilan menulis tegak bersambung pada peserta didik kelas II SDN 02 Macanan tahun ajaran 2020/2021 melalui 5 tahapan yaitu orientasi, presentasi/ demonstrasi, latihan terstruktur, latihan terbimbing, dan latihan mandiri. Hal itu terbukti dari peningkatan ketuntasan klasikal dari pratindakan 30\% menjadi 50\% pada siklus I, $70 \%$ pada siklus II, dan menjadi $90 \%$ pada siklus III. Kendala pada penggunaan metode Guided Writing untuk meningkatkan keterampilan menulis tegak bersambung ini yaitu peserta didik terkadang masih kurang percaya diri dalam menunjukkan hasil kerjanya sehingga sedikit memperlambat proses pembimbingan. Solusi dari kendala tersebut yaitu guru memberikan motivasi yang lebih kepada peserta didik untuk tampil percaya diri.

Implikasi dari penelitian ini secara teoretis bisa memperbanyak khazanah ilmu pengetahuan dalam pembelajaran menulis tegak bersambung, sedangkan secara praktis bisa dipakai guru sebagai acuan pembenahan kualitas pembelajaran daring maupun meningkatkan motivasi peserta didik untuk belajar menulis tegak bersambung. Saran untuk penelitian selanjutnya yaitu guru bisa mengembangkan media pembelajaran yang semakin menambah pemahaman peserta didik tentang apa yang dipelajarinya.

\section{DAFTAR PUSTAKA}

Daryanto. (2017). Pembelajaran Abad 21. Yogyakarta: Penerbit Gava Media.

Dianimdri, S. (2019). Peningkatan Keterampilan Menulis Tegak Bersambung Menggunakan Metode Pembelajaran Struktural Analitik Sintetik Peserta Didik Kelas II Sekolah Dasar. Didaktika Dwija Indria, 7(4).

Gibson, S. A. (2009). An Effective Framework for Primary-Grade Guided Writing Instruction. The Reading Teacher, 62(4), 324-334. Retrieved from http://www.jstor.org/stable/27699696

Kusniarti, T. (2015). Pembelajaran Menulis Naskah Drama dengan Strategi Menulis Terbimbing (SMT) sebagai Upaya Peningkatan Kreativitas Bersastra. Jurnal Keilmuan Bahasa, Sastra, Dan Pengajarannya, 1(1), 108-116.

Nurlatifah, H. (2020). Penerapan Metode Guided Writing Untuk Meningkatkan Keterampilan Menulis Deskripsi Sekolah Dasar Kelas Tinggi. Jurnal Perseda, III(1), 26-35. 
Volume 9 Nomor 1 Tahun 2021

Permendikbud. (2016). Permendikbud No. 24 Tahun 2014 Tentang Kompetensi Inti dan Kompetensi Dasar Pelajaran pada Kurikulum 2013 pada Pendidikan Dasar dan Pendidikan Menengah.

Sharp, L., \& Brown, T. (2015). Handwritings Instruction: An Analysis of Perspectives from Three Elementary Teacher. Texas Journal of Literacy, 3, 29.

Slamet, S. Y. (2014). Pembelajaran Bahasa dan Sastra Indonesia di Kelas Rendah dan Tinggi Sekolah Dasar. Surakarta: UNS Press.

Virgiawan, M. (2020). The Effectiveness of Guided Writing Combined with Virtual Reality Video as Teaching Media on Students' Writing Achievement. International Journal of Linguistics, Literature and Translation (IJLLT), 3(10). 